\title{
O LEGADO DE BRÁS CUBAS: O PRÍNCIPE MELANCÓLICO
}

\section{LUCIANA BRANDÃO LEAL}

Universidade Federal de Viçosa

Viçosa, Minas Gerais, Brasil

\section{ALEXANDRE VELOSO ABREU}

Pontifícia Universidade Católica de Minas Gerais

Belo Horizonte, Minas Gerais, Brasil

Resumo: Propõe-se uma leitura de Memórias Póstumas de Brás Cubas, de Machado de Assis, a partir do estudo da melancolia tal como ela se manifesta na voz da personagem Brás Cubas e da análise desse traço para além do universo ficcional em que a narrativa se inscreve.

Palavras-chave: Memórias Póstumas de Brás Cubas; narração; melancolia.

\section{THE LEGACY OF BRÁS CUBAS: THE MELANCHOLY PRINCE}

Abstract: This article puts forth a ready of Epitaph of a Small Winner, by Machado de Assis, that is based on the study of melancholy just as it appears in the voice of the character, Brás Cubas and the study of this trait beyond the fictional universe in which the narrative is recorded.

Keywords: Epitaph of a Small Winner; narration; melancholy. 
Machado de Assis em Linha — Universidade de São Paulo

http://machadodeassis.fflch.usp.br

No céu também há uma hora melancólica.

Hora dificil, em que a dúvida penetra as almas.

Por que fiz o mundo? Deus se pergunta.

E se responde: Não sei.

Carlos Drummond de Andrade, Antologia

Poética, p. 275

\section{Breve histórico do conceito de melancolia: o sentimento amargo e áspero}

melancolia (do grego mélas: negro e khólos: bile) é caracterizada por
um desequilíbrio humoral que provoca a oscilação entre dois
estados psíquicos opostos: o humor depressivo e o humor exaltado. Desde a Antiguidade a melancolia tematizou registros nas mais diversas áreas: do âmbito literário ao filosófico, da Medicina às Artes Plásticas. No princípio da Idade Média Ocidental, surge um novo termo para designar esse sentimento: acedia ou acídia (do grego akedia: indiferença): "A acedia era o primeiro fundamento da tristeza" (BENJAMIN, 2011, p. 225). Esse termo tem sentido de inércia, abatimento do corpo e do espírito, falta de interesse e vontade, ou mesmo melancolia profunda.

Na Antiguidade, atribuía-se a afecção melancólica à produção excessiva da atrabilis ou 'bile negra', transtorno que seria decorrente de um desequilíbrio no baço, o que ainda hoje está associado ao temperamento melancólico. Hipócrates de Cós (460-377 a.C.) e seus seguidores justificavam que a "doença do corpo e da alma" era fruto do desequilíbrio entre os quatro humores básicos do corpo: o sangue, a linfa, a bile amarela e a bile negra, que seriam responsáveis, respectivamente, pelos quatro temperamentos básicos, quais sejam: sanguíneo, fleumático, colérico e melancólico. Esses componentes, quando em perfeito equilíbrio, permitiriam a saúde corporal e mental do indivíduo; mas, segundo o "Pai da Medicina", quando há excesso da bile negra, ocorre a perda do amor pela vida, "uma situação na qual a pessoa aspira à morte como se fosse uma bênção" (HIPÓCRATES ${ }^{1}$ apud SCLIAR, 2003, p. 70).

A partir da interação dos temperamentos sanguíneos, alguns autores especialmente árabes -, no século IX, estabeleceram relação entre os

\footnotetext{
${ }^{1}$ HIPÓCRATES (460-377 a.C.). Sobre o riso e a loucura. Organização e tradução de Rogério Gimenes de Campos. São Paulo: Hedra, 2011.
} 
Machado de Assis em Linha — Universidade de São Paulo http://machadodeassis.fflch.usp.br

humores e os planetas. O humor sanguíneo corresponderia a Júpiter; o colérico, a Marte; o fleumático, a Vênus; e o melancólico, a Saturno, planeta distante da Terra, de lenta rotação. Walter Benjamin (2011), a propósito, explica que, para a ciência do mundo árabe, na época, o estudo sobre a melancolia estava profundamente ligado à doutrina da influência dos astros: "E entre essas influências só a mais funesta, a de Saturno, presidia a disposição de ânimo melancólica" (BENJAMIN, 2011, p. 155). Saturno seria "um astro pouco auspicioso" (SCLIAR, 2003, p. 74), cuja luz, triste e fraca, evoca, desde os primeiros tempos, as tristezas e as provocações da vida. Para Walter Benjamin:

A meditação profunda do espírito perturbado é atribuída à influência de Saturno, que, como planeta supremo, o mais afastado da vida quotidiana, é responsável por aquela funda contemplação que leva a alma a desviar a atenção das coisas exteriores para o interior, fazendo-a subir cada vez mais alto e finalmente lhe concede o saber supremo e dons proféticos. (BENJAMIN, 2011, p. 155)

A bile negra teria poderosa ação sobre a mente humana; daí a recorrente associação da melancolia aos indivíduos notáveis e geniais. Considerando o famoso questionamento de Aristóteles, que busca responder: "Por que todos os que foram homens de exceção, no que concerne à filosofia, à ciência do Estado, à poesia ou às artes, são manifestamente melancólicos?" (ARISTÓTELES, 1998, p. 81), Moacyr Scliar explica que "o temperamento melancólico é um temperamento metafórico, propenso, pois, à criação - na filosofia, na poesia, nas artes" (SCLIAR, 2003, p. 70). Entretanto, essa notabilidade tem um preço: "esse talento os arrebata e os conduz pela vida como um 'barco sem lastro'" (SCLIAR, 2003, p. 70).

Aristóteles (1998), por sua vez, compara os efeitos da bile negra aos do vinho no organismo humano e justifica que ambos podem acentuar a excepcionalidade do indivíduo e definir sua volubilidade. Para ele, os efeitos da embriaguez são semelhantes aos da melancolia, porque desencadeiam comportamentos excêntricos quando confrontados com os esperados em estado de lucidez. Aristóteles sugere que:

O vinho, com efeito, tomado em abundância, parece deixar as pessoas totalmente da maneira como descrevemos os melancólicos, e sua absorção produzir um muito grande número [sic] de caracteres, por 
Machado de Assis em Linha — Universidade de São Paulo

http://machadodeassis.fflch.usp.br

exemplo, os coléricos, os filantropos, os apiedados, os audaciosos. (ARISTÓTELES, 1998, p. 83)

A partir dessa comparação, esse filósofo estabelece que os melancólicos são indivíduos instáveis, que deambulam entre os estados de euforia e depressão, demonstrando, assim, profundo desinteresse pela vida. Entretanto, ao aproximar as reações causadas pelo vinho e pela bile negra, Aristóteles faz questão de estabelecer uma diferença: os efeitos do vinho são temporários, ao passo que, no melancólico, os efeitos da bile negra são permanentes, porque se fundam na natureza do indivíduo: "O vinho, portanto, cria a exceção no indivíduo não por muito tempo, mas por um curto momento, enquanto que a natureza produz esse efeito para sempre, por todo tempo em que se vive" (ARISTÓTELES, 1998, p. 87).

O século XX trouxe para a reflexão sobre a melancolia a contribuição de Sigmund Freud. Esse "pai da Psicanálise" retoma a antiga acepção de melancolia, tomando-a não apenas como uma doença, mas como uma alteração subjetiva. No ensaio Luto e melancolia, Freud relaciona esses dois sintomas à intolerância frente à perda de um objeto amado - "de uma pessoa querida ou de uma abstração que esteja no lugar dela, como pátria, liberdade, ideal etc." (FREUD, 2011, p. 47) -, que desperta um sentimento profundamente amargo, além da indiferença social e do retraimento do eu. Freud aponta, nos melancólicos, uma disposição patológica, e assim descreve as reações comuns a ela:

A melancolia se caracteriza por um desânimo profundamente doloroso, uma suspensão do interesse pelo mundo externo, perda da capacidade de amar, inibição de toda atividade e um rebaixamento do sentimento de autoestima, que se expressa em autorrecriminações e autoinsultos, chegando até a expectativa delirante de punição. (FREUD, 2011, p. 47)

Esses mesmos traços aparecem nos enlutados, exceto um: no luto, não há perda da autoestima: "No luto é o mundo que se tornou pobre e vazio; na melancolia, é o próprio ego" (FREUD, 2011, p. 53). O sujeito melancólico experimenta diminuição extraordinária da autoestima, com empobrecimento do ego em grande escala, o que é descrito por Freud nestes termos:

O doente nos descreve seu ego como indigno, incapaz e moralmente desprezível; ele se recrimina, se insulta e espera ser rejeitado e 
Machado de Assis em Linha - Universidade de São Paulo

http://machadodeassis.fflch.usp.br

castigado. Humilha-se perante os demais e tem pena dos seus por estarem eles ligados a uma pessoa tão indigna. Não julga que lhe aconteceu uma mudança, mas estende sua autocrítica ao passado: afirma que ele nunca foi melhor. O quadro desse delírio de inferioridade - predominantemente moral - se completa com insônia, recusa de alimento e uma superação - extremamente notável do ponto de vista psicológico - da pulsão que compele todo ser vivo a se apegar à vida. (FREUD, 2011, p. 53)

Em Luto e melancolia (2011), esse psicanalista evidencia que, apesar das semelhanças entre essas duas pulsões, o trabalho do luto consiste em que, findada a elaboração da dor, o sujeito consiga substituir o objeto perdido por outro e, consequentemente, volte à vida. Freud ressalta que "a perda do objeto de amor é uma oportunidade extraordinária para que entre em vigor e venha à luz a ambivalência das relações amorosas" (FREUD, 2011, p. 65). Esse processo falha quando abordamos a melancolia, porque o sujeito melancólico não sabe exatamente o que lhe falta e não consegue concluir o processo de elaboração da dor. A partir dessa reflexão, Freud conclui: "A inibição melancólica nos dá uma impressão mais enigmática, porque não podemos ver o que absorve tão completamente os doentes" (FREUD, 2011, p. 53).

Sigmund Freud classifica a melancolia como um tipo de "neurose narcísica" e alerta que "uma parte das características da melancolia é tomada de empréstimo ao luto e outra parte do processo de regressão da escolha narcísica de objeto ao narcisismo" (FREUD, 2011, p. 65). Ele sugere que, em função da identificação do ego com o objeto perdido, há um retorno da libido em direção ao eu; por isso, no melancólico, a perda do objeto pode se transformar na perda do próprio ego. Maria Rita Kehl explica que algumas ideias retomadas por Freud em Luto e melancolia (cuja primeira edição é de 1915), foram anunciadas em Introdução ao narcisismo (publicado, originalmente, em 1914), porque aí se lê:

O autoerotismo participa dos modos de satisfação da libido do eu. [...]. Além da satisfação libidinal autoerótica, o infans haverá de identificarse com o objeto privilegiado que ele representa frente ao amor e ao desejo de seus pais. A partir desse ponto, está estabelecida a base para a formação da unidade do ego freudiano, fonte de investimento libidinal e dessa forma particular de amor a que chamamos narcisista. Nesse ponto da constituição psíquica, Freud haverá de encontrar, em 1915, a relação 
Machado de Assis em Linha — Universidade de São Paulo

http://machadodeassis.fflch.usp.br

narcísica com um objeto frustrante que marca a estrutura da melancolia. (KEHL, 2011, p. 17)

Freud parte da interpretação do mito de Narciso, "flor do luto e da morte", um sujeito que se apaixona por si mesmo - como se o ego fosse o objeto do próprio amor. Urânia Tourinho, em comentários publicados no livro Luto e melancolia, sintetiza o mito de Narciso, a fim de esclarecer a analogia proposta por Freud, nestes termos:

Narciso foi aquele que, ao se contemplar nas águas de uma fonte, fascinado pela beleza de sua imagem, enamora-se dela. Desesperado por não poder alcançar o objeto de seu amor, morre à beira d'água. De seu corpo ferido e sangrando surge uma flor: o narciso. Entre ele e sua imagem faltou a presença de um terceiro, que o retirasse da trama especular. Faltou-lhe a presença desse Outro que lhe daria reconhecimento, matriz do sentimento de si, base da formação do eu (ego). Narciso fica aprisionado na fascinação de olhar a própria imagem como se fosse um outro. (FREUD, 2011, p. 117)

O termo "narcisismo", então, passou a identificar o Homem moderno: individualista, muito preocupado consigo mesmo, com a própria aparência e com status social. Os grandes progressos da Ciência e da Técnica não o tornaram mais feliz; ao contrário, o Homem está cada vez mais voltado para si e indiferente ao outro. Visando atingir um ideal culturalmente e socialmente estabelecido, o indivíduo moderno é submetido a uma série de frustrações. A sociedade moderna incentiva o desenvolvimento de patologias narcísicas; entre elas, a melancolia.

\section{Marcado pelo signo de Saturno}

A partir dessas considerações sobre o conceito de melancolia, refletese, aqui, sobre como este sentimento dá o tom às memórias de Brás Cubas, determinando o que será lembrado e o que será esquecido. O estudo da melancolia para além do universo ficcional confere acesso privilegiado à perspectiva do narrador e, portanto, à compreensão de Memórias póstumas de Brás Cubas (ASSIS, 2012). As experiências desse filho abastado da elite brasileira - seus amores, veleidades e frustrações - são o ponto de partida para uma crítica social explícita. Suas memórias ficcionais, escritas além- 
Machado de Assis em Linha — Universidade de São Paulo http://machadodeassis.fflch.usp.br

túmulo, traduzem aspectos do "real vivido", enfatizando a falência moral, as injustiças e os privilégios da elite brasileira do século XIX, personificada na figura de Brás.

Memórias póstumas de Brás Cubas (ASSIS, 2012) evidencia a trajetória de um sujeito egoísta, cheio de vontades e caprichos, amante das mordomias e do dinheiro mas, por vezes, abatido e angustiado com os sucessivos fracassos que a vida lhe impôs, mesmo tendo nascido em berço de ouro. $\mathrm{O}$ finado-autor admite: "foi assim que me encaminhei para o undiscovered country de Hamlet, sem as ânsias nem as dúvidas do moço príncipe, mas pausado e trôpego, como quem se retira tarde do espetáculo" (ASSIS, 2012, p. 28).

Hamlet refere-se ao undiscovered country - expressão metafórica para a morte - no trecho mais conhecido da tragédia homônima de Shakespeare (2009), em que esse príncipe da Dinamarca declama o famoso "To be, or not to be, that is the question". Nesse momento, Hamlet faz alusão à morte como um "país desconhecido", de onde nenhum viajante pôde regressar, e, como interpreta Marta de Senna:

O undiscovered country onde se acha o narrador Brás Cubas é o lugar da narrativa, sem dúvida, mas o retardamento, ou a ausência de ação, o torpor psicológico e social de Brás personagem e, acima de tudo, a indecidibilidade de Brás narrador, sua volubilidade, são evidências inequívocas da presença da tragédia no romance, saindo ambos (e nós) enriquecidos por ela. (SENNA, 2008, p. 53-54)

Ao se comparar a Hamlet, Brás Cubas se aproxima desse príncipe melancólico que, mesmo dotado de imaginação peculiar, é incapaz de vingar a morte do pai - que o deixa profundamente desiludido com o mundo. Moacyr Scliar justifica, nestes termos, esse comportamento de Hamlet: "A melancolia é uma resposta ao mundo doente do qual ela própria se origina. A imagem do 'príncipe melancólico', assim como a do 'monarca melancólico', não era rara à época" (SCLIAR, 2003, p. 89).

O herói de Memórias póstumas é, por natureza, um sujeito hipocondríaco e melancólico, entregue a reflexões insistentes sobre as coisas e as formas de agir dos homens. Walter Benjamin (2011) esclarece que a bile negra desafia permanentemente o espírito a se dirigir a um ponto e a se concentrar nele para, aí, se entregar à contemplação. Como a bile negra é, em si mesma, semelhante ao centro do mundo, ela obriga o ser a investigar o 
Machado de Assis em Linha — Universidade de São Paulo

http://machadodeassis.fflch.usp.br

centro de todas as coisas singulares e leva à compreensão das mais profundas verdades.

Em sua empreitada memorialística, Brás Cubas se empenha no processo de autoconhecimento e suas experiências individuais o fazem refletir sobre as misérias da condição humana. Desse modo, ele pode se analisar introspectivamente, investigando as causas de sua própria melancolia - e nada melhor, nesse sentido, do que a opção pelo gênero autobiográfico. O defunto-autor resolve escrever uns magros capítulos para "distrai[r] um pouco da eternidade" (ASSIS, 2012, p. 156), mas acaba por traçar um autorretrato no qual revela a sua verdadeira face e a mediocridade de sua vida passada.

Talvez cause ao leitor certa estranheza o fato de o narrador alardear suas baixezas e sua indignidade, sem demonstrar sentimento de vergonha ou arrependimento. A teoria psicanalítica de Freud justifica que, no melancólico, sobressai-se o desejo de comunicar ao mundo os próprios defeitos, como se, nesse rebaixamento, ele encontrasse um tipo de satisfação. Esse tipo de comportamento é comum na melancolia, porque os sujeitos atormentados por essa patologia acreditam que: "Queixar-se é dar queixa, no velho sentido do termo; eles não se envergonham nem se escondem, porque tudo de depreciativo que dizem de si mesmos no fundo dizem de outrem" (FREUD, 2011, p. 59).

Nosso herói acredita que a Natureza é má e madrasta, indiferente ao homem e aos seus esforços. Brás Cubas narra seu delírio em um capítulo significativo, que Letícia Malard (2012) considera ser um dos mais "famosos, originais e de mais difícil interpretação da literatura brasileira" (ASSIS, 2012, p. 47). A compreensão desse célebre registro é condição fulcral para o entendimento do niilismo propagado no romance, porque o delírio é uma espécie de tese de que a narrativa da vida de Brás Cubas será confirmação. Nesse capítulo, o narrador aborda os grandes temas filosóficos: a origem da vida, a civilização, a (in)felicidade e a insignificância do homem frente à Natureza.

O narrador adverte, a princípio, sobre a novidade daquilo que pretende contar: "Que me conste, ainda ninguém relatou o seu próprio delírio; faço-o eu, e a ciência mo agradecerá" (ASSIS, 2012, p. 39). Além disso, tenta convencer o leitor de que "não é dado à contemplação destes fenômenos mentais" (ASSIS, 2012, p. 39), garantindo-lhe: "é interessante saber o que se passou na minha cabeça durante uns vinte a trinta minutos" (ASSIS, 2012, p. 40). 
Machado de Assis em Linha — Universidade de São Paulo http://machadodeassis.fflch.usp.br

O delírio precede a morte do protagonista e é repleto de símbolos, mediadores do diálogo estabelecido entre ele e a Natureza, ou Pandora. Nesse diálogo, delineiam-se alguns temas que posteriormente serão abordados pelo defunto-autor - como se fosse uma "profissão de fé" de um sujeito desencantado. No período de desordem mental, Brás Cubas dá forma e expressão aos seus últimos pensamentos e, por meio deles, comunica a sua concepção de vida, além de uma filosofia existencial.

Segundo a mitologia grega, Pandora é o arquétipo da origem dos males da Humanidade, dos desencontros e da infelicidade. "Primeira humana da mitologia pagã, tão bela e perfeita quanto as deusas" (comentário de Letícia Malard - ASSIS, 2012, p. 42). Fora criada por Zeus para punir os homens que receberam as sementes de fogo roubadas por Prometeu. Epimeteu, irmão de Prometeu e marido de Pandora, confiou a ela uma caixa, onde havia um terrível segredo. Apesar da proibição de abri-la, Pandora não resiste à curiosidade, abre a caixa e liberta os males, guardando apenas a esperança. Retida para sempre, a esperança perde o sentido de virtude e se transforma na "voluptuosidade do nada". A partir de então, foram os homens afligidos e atormentados por todos os males.

O narrador assim descreve a figura de mulher que se impôs a ele, fitando-o com os olhos rutilantes como o Sol: "Tudo nessa figura tinha a vastidão das formas selváticas, e tudo escapava à compreensão do olhar humano" (ASSIS, 2012, p. 42).

A Natureza, ou Pandora, se apresenta como "mãe e inimiga", o que seria, a princípio, uma contradição, mas se confirma pela postura sempre indiferente aos apelos humanos. A colossal imagem se opõe ao narrador consternado e, ao contrário de uma figura maternal e protetora, revela seu "rosto indiferente, como o sepulcro" (ASSIS, 2012, p. 43), "a feição única, geral, completa, era a da impassibilidade egoísta, a da eterna surdez, a da vontade imóvel" (ASSIS, 2012, p. 43).

Prevalece, então, o sentimento da perda de sentidos, tão comum ao melancólico, do absurdo irremediável da condição humana: "tu és absurda, tu és uma fábula" (ASSIS, 2012, p. 43), sugere o protagonista, diante de uma realidade que ele não consegue aceitar ou entender. No período de confusão mental, o humor dominante é de angústia e espanto: "Estou sonhando, decerto, ou, se é verdade que enlouqueci, tu não passas de uma concepção de alienado, isto é, uma cousa vã, que a razão ausente não pode reger nem palpar" (ASSIS, 2012, p. 43). 
Machado de Assis em Linha — Universidade de São Paulo http://machadodeassis.fflch.usp.br

Brás Cubas é, então, levado, ao alto de uma montanha, a fim de contemplar o espetáculo da Humanidade, numa espécie de "condensação viva de todos os tempos" (ASSIS, 2012, p. 44). Os séculos passaram-se como um turbilhão, sob seus olhos delirantes, e ele pôde reconhecer, na Humanidade, seus flagelos e suas delícias, a glória e a miséria:

Aí vinham a cobiça que devora, a cólera que inflama, a inveja que baba, e a enxada e a pena, úmidas de suor, e a ambição, a fome, a vaidade, a melancolia, a riqueza, o amor, e todos agitavam o homem, como um chocalho, até destruí-lo, como um farrapo. (ASSIS, 2012, p. 44)

Traços profundos da personalidade do melancólico são, assim, revelados pelo delírio. A dor só se alivia pela indiferença, "sono sem sonhos"; ou pelo prazer, "que é uma dor bastarda":

A dor cedia alguma vez, mas cedia à indiferença, que era um sono sem sonhos, ou ao prazer, que era uma dor bastarda. Então o homem, flagelado e rebelde, corria diante da fatalidade das cousas, atrás de uma figura nebulosa e esquiva, feita de retalhos, um retalho de impalpável, outro improvável, outro de invisível, cosidos todos a ponto precário, com a agulha da imaginação; e essa figura, - nada menos que a quimera da felicidade, - ou lhe fugia perpetuamente, ou deixava-se apanhar pela fralda, e o homem a cingia ao peito, e então ela ria, como um escárnio, e sumia-se, como uma ilusão. (ASSIS, 2012, p. 45)

Ao contemplar tanta calamidade, o narrador reage com um grito angustiado e, mesmo em face desse horror, a Natureza, ou Pandora, permanece impassível, "escut[a] sem protestar nem rir; e não sei por que lei de transtorno cerebral, fui eu que me pus a rir, - de um riso descompassado e idiota" (ASSIS, 2012, p. 45). Augusto Meyer (2008) postula que, para Brás Cubas, a Natureza é um imenso absurdo, e essa visão de mundo é sumarizada no delírio, que provoca o riso como reação inconsciente.

Foi assim que o moribundo viu passar os séculos, "velozes e turbulentos", pôde ver o "desfilar de todos eles, as raças todas, todas as paixões, o tumulto dos impérios, a guerra dos apetites e dos ódios, a destruição recíproca dos seres e das cousas" (ASSIS, 2012, p. 46). Cada século trazia um tanto de luz e sombra, de glória e miséria, de verdade e de erro. Já enfarado do espetáculo e, por isso, distraído, o narrador vê chegar o seu século: "Aquele vinha ágil, destro, vibrante, cheio de si, um pouco difuso, 
Machado de Assis em Linha — Universidade de São Paulo

http://machadodeassis.fflch.usp.br

audaz, sabedor, mas ao cabo tão miserável como os primeiros, e assim passou e assim passaram os outros, com a mesma rapidez e igual monotonia" (ASSIS, 2012, p. 46).

Na perspectiva desse narrador, a vida é um constante flagelo; ruínas sobre ruínas vão se amontoando. Nada resiste ao "enxurro da vida" (ASSIS, 2012, p. 86). Marcela, que era linda, envelhece; sua extrema beleza se reduz a bexigas sob os olhos. O amor por Virgília transforma-se em uma paixão adúltera e, depois, em cinzas. A bela e altiva Eugênia é coxa. Eulália, a noiva de Brás, morre em decorrência da febre amarela, aos dezenove anos. Brás Cubas almejou ser pai e não conseguiu; quis ser ministro, mas o espaço em branco no capítulo "De como não fui ministro d'Estado" mostra outro objetivo frustrado: "Foi califa, mas só na imaginação de um louco, pois é Quincas Borba quem o nomeia" (ROUANET, 2007, p. 51).

As frustrações desse protagonista conferem um tom especial ao romance, numa vida em que nenhum projeto se conclui, afinal, nada é perseguido com firmeza. A narrativa evolui em um palco onde prevalece a "decomposição dos seres e das experiências" (MERQUIOR, 1979, p. 169), todas as relações e objetivos se esvaem, tudo apodrece. Não por acaso, o defunto-autor avisa aos leitores que o livro "cheira a sepulcro, traz certa contração cadavérica" (ASSIS, 2012, p. 156). As perdas, recorrentes na vida de Brás Cubas, são responsáveis por moldar seu caráter, o de um sujeito marcado pelo signo de Saturno:

Usualmente, quando eu perdia o sono, o bater da pêndula fazia-me muito mal; esse tic-tac soturno, vagaroso e seco parecia dizer a cada golpe que eu ia ter um instante menos de vida. Imaginava então um velho diabo, sentado entre dous sacos, o da vida e da morte, a tirar as moedas da vida para dá-las à morte, e a contá-las assim:

- Outra de menos...

- Outra de menos...

- Outra de menos... (ASSIS, 2012, p. 132)

O primeiro momento em que Brás Cubas torna evidente a sua melancolia é por ocasião da morte da sua mãe. Essa perda, que o defuntoautor traz latente na memória, é descrita minuciosamente, em ritmo progressivo e implacável, semelhante ao do câncer que corroeu o estômago daquela "senhora fraca, de pouco cérebro e muito coração" (ASSIS, 2012, p. 53). O narrador descreve, em minúcias, a morte da sua mãe, no capítulo XXIII - "Triste, mas curto": 
Machado de Assis em Linha - Universidade de São Paulo

http://machadodeassis.fflch.usp.br

Longa foi a agonia, longa e cruel, de uma crueldade minuciosa, fria, repisada, que me encheu de dor e estupefação. Era a primeira vez que eu via morrer alguém. Conhecia a morte de oitiva; quando muito, tinhaa visto já petrificada no rosto de algum cadáver, que acompanhei ao cemitério, ou trazia-lhe a ideia embrulhada nas amplificações de retórica dos professores de cousas antigas, - a morte aleivosa de César, a austera de Sócrates, a orgulhosa de Catão. Mas esse duelo do ser e do não-ser, a morte em ação, dolorida, contraída, convulsa, sem aparelho político ou filosófico, a morte de uma pessoa amada, essa foi a primeira vez que a pude encarar. Não chorei; lembra-me que não chorei durante o espetáculo: tinha os olhos estúpidos, a garganta presa, a consciência boquiaberta. Quê? uma criatura tão dócil, tão meiga, tão santa, que nunca jamais fizera verter uma lágrima de desgosto, mãe carinhosa, esposa imaculada, era força que morresse assim, trateada, mordida pelo dente tenaz de uma doença sem misericórdia? Confesso que tudo aquilo me pareceu obscuro, incongruente, insano... (ASSIS, 2012, p. 86-87)

Uma declaração feita nesse capítulo, transcrita acima, chama a atenção: "Era a primeira vez que eu via morrer alguém [...]" (ASSIS, 2012, p. 86). Mesmo tendo presenciado a morte de Leocádia, viúva do capitão, o narrador trata de explicar o que, para ele, significa ser a "primeira vez". Esclarece que há três formas diferentes de se conhecer a morte: a primeira, de "oitiva", é a maneira daqueles que só conhecem a morte de ouvir falar, forma distante e impessoal; a segunda, caracteriza-se pela visão da morte "petrificada no rosto de algum cadáver" (ASSIS, 2012, p. 86); a terceira, por fim, advém do conhecimento da morte de grandes personalidades históricas. Brás Cubas afirma que nenhuma dessas três formas representa um conhecimento autêntico, já que apenas a experiência da perda de uma pessoa amada é efetivamente "dolorida, contraída, convulsa" (ASSIS, 2012, p. 86).

Em contato com a morte e com as falências humanas, testemunha da "destruição [...] dos seres e das cousas", Brás Cubas reflete: "Tal era o espetáculo, acerbo e curioso espetáculo" (ASSIS, 2012, p. 44). Curiosamente, nas duas vezes em que o protagonista viu a morte de bem perto - no episódio de Leocádia e no caso da morte da mãe -, tem-se a ideia de "espetáculo". Quanto à primeira ocasião, ele confessa ter "fugi[do] ao espetáculo" (ASSIS, 2012, p. 86), por considerá-lo repugnante. Com relação à segunda, diz não ter chorado durante esse espetáculo, porque "tinha os olhos estúpidos, a garganta presa, a consciência boquiaberta" (ASSIS, 2012, p. 87). 
Machado de Assis em Linha - Universidade de São Paulo http://machadodeassis.fflch.usp.br

Após a morte de sua mãe, Brás Cubas resolve passar alguns dias no alto da Tijuca. O seu primeiro efetivo contato com a morte faz com que ele experimente o luto e, por isso, a sua sensação é de perda do sentido da vida, o que o leva a renunciar a tudo e a entrar em um estado de introspecção. Nessa ocasião, esse narrador lembra os versos de Shakespeare na fala do hipocondríaco Jacques a Rosalinda: "Que bom que é estar triste e não dizer cousa nenhuma!" (ASSIS, 2012, p. 90); e tece, a seguir, este comentário:

Quando esta palavra de Shakespeare me chamou a atenção, confesso que senti em mim um eco, um eco delicioso. Lembra-me que estava sentado, debaixo de um tamarineiro, com o livro do poeta aberto nas mãos, e o espírito ainda mais cabisbaixo do que a figura, - ou jururu, como dizemos das galinhas tristes. (ASSIS, 2012, p. 90)

Aperta-lhe o peito uma dor taciturna, à qual denomina "volúpia do aborrecimento". Essa sensação única é assim descrita pelo melancólico Brás Cubas: "Volúpia do aborrecimento: decora esta expressão, leitor; guarda-a, examina-a, e se não chegares a entendê-la, podes concluir que ignoras uma das sensações mais sutis desse mundo e daquele tempo" (ASSIS, 2012, p. 90).

Inspirada pelas palavras de Jacques, personagem de Shakespeare, Regina Zilberman (2012) entende que a melancolia de Brás Cubas é uma "melancolia própria". Essa "coloração específica" é, em parte, provocada pela morte da mãe e, em outra parte, é herança dessa mãe. Essa afirmação é feita pela escritora gaúcha no livro Brás Cubas autor Machado de Assis leitor, e está fundamentada na pesquisa das fontes primárias de Memórias póstumas de Brás Cubas. Esses apontamentos podem ser confirmados pelo trecho, transcrito a seguir, publicado na primeira edição do romance (de 1881), que foi, mais tarde, suprimido, no qual o protagonista descreve a origem de seu temperamento melancólico:

Tão boa, tão simples, minha mãe guardava no fundo do coração uma sombra de melancholia, que eu herdei, como herdei de meu pae a fatuidade. De si mesma era melancholica; penso, entretanto, que os aspectos da vida lhe accrescentaram a tendencia natural. Tinha coração de mais, uma sensibilidade melindrosa, exigente, doentia. Uma e outra dessas qualidades se combinavam e alternavam na minha pessoa. (ASSIS, $1881^{2}$ apud ZILBERMAN, 2012, p. 69)

\footnotetext{
${ }^{2}$ ASSIS, Machado de. Memórias póstumas de Brás Cubas. Rio de Janeiro: Tipografia Nacional, 1881.
} 
Machado de Assis em Linha — Universidade de São Paulo http://machadodeassis.fflch.usp.br

Essa situação de tristeza e solidão deu origem, no protagonista, à hipocondria: "Creio que por então é que começou a desabotoar em mim a hipocondria, essa flor amarela, solitária e mórbida, de um cheiro inebriante e subtil" (ASSIS, 2012, p. 90). A hipocondria, popularmente conhecida como uma obsessão doentia por manter a própria saúde, tem como principal sintoma a preocupação excessiva com a morte. A cor amarela é bastante significativa, prenúncio da velhice e da morte, como pontua Jean Chevalier: "cor das espigas maduras do verão já anuncia a do outono, quando a terra se desnuda, perdendo seu manto de verdura" (CHEVALIER, 2009, p. 41).

Passados sete dias, ainda na chácara, Brás Cubas tenta reagir ao estado melancólico, porque estava farto da solidão, "a dor aplacara" e ele decidiu que "era preciso viver" (ASSIS, 2012, p. 90). O pai, "partidário da vida brilhante" (SCHWARZ, 2000, p. 99), não perdeu tempo, chegou com "duas propostas na algibeira" (ASSIS, 2012, p. 92) e reavivou-lhe a memória, repetindo-lhe a velha sabedoria familiar:

- Ah! brejeiro! Contanto que não te deixes ficar aí inútil, obscuro, e triste; não gastei dinheiro, cuidados, empenhos, para te não ver brilhar, como deves, e te convém, e a todos nós; é preciso continuar o nosso nome, continuá-lo e ilustrá-lo ainda mais. (ASSIS, 2012, p. 96)

Foram muitos os incentivos; além disso, o pai trouxe-lhe dois projetos: "um lugar de deputado e um casamento" (ASSIS, 2012, p. 92). Bento Cubas procura entusiasmar o filho, e a ele afiança: "Olha que os homens valem por diferentes modos, e que o mais seguro de todos é valer pela opinião dos outros homens. Não estragues as vantagens da tua posição, os teus meios..." (ASSIS, 2012, p. 96-97).

Entre a sede da nomeada e a volúpia do aborrecimento, o narrador hesita. Decide, então, tornar à vida, optando pelo "amor da nomeada":

E foi por diante o mágico, a agitar diante de mim um chocalho, como me faziam, em pequeno, para eu andar depressa, e a flor da hipocondria recolheu-se ao botão para deixar a outra flor menos amarela, e nada mórbida, - o amor da nomeada, o emplasto Brás Cubas. (ASSIS, 2012, p. 97)

No decorrer da narrativa, o protagonista transita entre a "hipocondria" e o "amor da nomeada", entre a "apatia" e o "bulício", forças que movem o espírito de Brás Cubas. Como nos conta o próprio narrador, sua vida 
Machado de Assis em Linha — Universidade de São Paulo http://machadodeassis.fflch.usp.br

transcorre "ao curso e recurso dos sucessos e dos dias, ora buliçoso, ora apático, entre a ambição e o desânimo" (ASSIS, 2012, p. 122).

Nosso herói é um saturnino, marcado pelo signo de Saturno, que é, também, o planeta das antíteses, o que justifica, em Brás Cubas, a correlação de atributos tão contraditórios. Para Walter Benjamin, tal como ocorre com a melancolia, Saturno é o planeta dos contrastes e, por isso,

Investe na alma, por um lado com a indolência e a apatia, por outro com a força da inteligência e da contemplação; como ela, também ele ameaça os que lhe estão sujeitos, por mais distintos que sejam esses espíritos, com os perigos da hipocondria ou da demência extática. (BENJAMIN, 2011, p. 156)

Em Memórias póstumas de Brás Cubas, há duas referências explícitas ao planeta Saturno: a primeira, feita no capítulo CIII; e a segunda, no capítulo CXXXV. No capítulo CIII, "Distração", o protagonista relata o momento em que escuta, desinteressado, as queixas de Virgília, insatisfeita com o descaso do amante. Enquanto isso, Brás tinha os braços amparados no joelho, o olhar atento ao chão, onde uma mosca e uma formiga se engalfinhavam: "olhava para o chão, onde uma mosca arrastava uma formiga que lhe mordia o pé" (ASSIS, 2012, p. 198). Essa situação e tais agentes adquirem nessa passagem o valor de reduplicação do que está acontecendo com as personagens. "Pobre mosca! pobre formiga!" (ASSIS, 2012, p. 198). O prenúncio do fim da relação amorosa entre Brás Cubas e Virgília é ilustrado pela luta de dois insetos, que são separados pelas mãos de Brás, no momento em que ele afirma ter calculado a distância entre sua mão e o planeta Saturno.

Na segunda ocorrência, no capítulo CXXXV, "Oblivion", o protagonista contempla o espetáculo dos amores que se sucedem e se transformam em esquecimento, palavra grafada em inglês e em versalete: OBLIVION! (ASSIS, 2012, p. 232). A mudança dos tempos, "tempora mutantur", é aclarada pelos dizeres: "cousa é não achar já quem se lembre de meus pais, e de que modo me há de encarar o próprio ESQUECIMENTo" (ASSIS, 2012, p. 232). A efemeridade e a transitoriedade da vida são o cerne desse capítulo, constatações pertinentes ao espírito melancólico. O espetáculo da fugacidade da vida (e da morte) tem por finalidade divertir um astro: "Espetáculo, cujo fim é divertir o planeta Saturno, que anda muito aborrecido" (ASSIS, 2012, p. 232). 
Machado de Assis em Linha — Universidade de São Paulo http://machadodeassis.fflch.usp.br

Podemos interpretar essas duas ocorrências como exemplos clássicos do comportamento de um sujeito melancólico, frente às frustrações que lhe são impostas pela brevidade do tempo. Esse pessimismo é aliado à consciência de que o homem está fadado às ruínas do tempo, porque impera, segundo Afrânio Coutinho:

A transitoriedade de tudo, o aspecto destruidor e corruptor do tempo, conduzindo à decadência física e à morte, a inanidade de qualquer esforço, pois o fim é o mesmo, o escoamento implacável, a perecibilidade do ser humano contrastando com o ideal da vida perpétua, a descontinuidade humana, o nada como fim de todas as coisas e seres. (COUTINHO, 1990, p. 86)

Foi essa mesma melancolia que despertou nele, tempos depois, a necessidade da invenção de um emplasto anti-hipocondríaco. Brás Cubas descreve a situação em que foi tomado por essa ideia fixa:

Com efeito, um dia de manhã, estando a passear na chácara, pendurouse-me uma ideia no trapézio que eu tinha no cérebro. Uma vez pendurada, entrou a bracejar, a pernear, a fazer as mais arrojadas cabriolas de volatim, que é possível crer. $\mathrm{Eu}$ deixei-me estar a contemplá-la. Súbito, deu um grande salto, estendeu os braços e as pernas, até tomar a forma de um X: decifra-me ou devoro-te. (ASSIS, 2012, p. 30)

Uma ideia "quase" fixa porque, como afirma o narrador, não há nada "assaz fixo nesse mundo": "talvez a lua" ou "a finada dieta germânica" (ASSIS, 2012, p. 34).

A propósito, Brás Cubas só não tratou a pneumonia que o levou à morte porque trazia no cérebro uma "ideia fixa dos doudos e dos fortes" (ASSIS, 2012, p. 35), a invenção do emplasto: "estando eu ocupado em preparar e apurar a minha invenção, recebi em cheio um golpe de ar; adoeci logo, e não me tratei" (ASSIS, 2012, p. 35). Parece-nos que a verdadeira "ideia fixa" é explorar até a última instância o ridículo de um empreendimento atravessado na cabeça do narrador. No capítulo "Das negativas", o reminiscente atesta mais um de seus fracassos que, embora tenha sido uma ideia "grandiosa e útil", não apenas morre com ele, mas é também a causa de sua morte: "Divino emplasto, tu me darias o primeiro lugar entre os homens, acima da ciência e da riqueza, porque eras a genuína e direta inspiração do 
Machado de Assis em Linha — Universidade de São Paulo http://machadodeassis.fflch.usp.br

céu. O acaso determinou o contrário; e aí vos ficais eternamente hipocondríacos" (ASSIS, 2012, p. 256).

O emplasto anti-hipocondríaco fracassou, o que já era esperado, porque, como observa Rouanet (2007), o narrador de Memórias póstumas de Brás Cubas não era sério o suficiente para produzir coisa alguma. Além disso, eis o que sempre faltou a Brás Cubas: ousadia e determinação, sobrando-lhe melancolia e tédio.

A melancolia triunfa sobre a invenção que poderia curá-la, e isso não ocorre somente porque a morte do protagonista interrompeu a execução do seu projeto revolucionário, mas porque a ideia do medicamento era, em si mesma, pura galhofa, não passava de uma "pirueta de trapezista, que nunca ameaçaria realmente o reinado da melancolia" (ROUANET, 2007, p. 221).

Já que a melancolia não pôde ser curada por nenhuma panaceia antihipocondríaca, resta ao narrador zombar de tudo e de todos; especialmente, daqueles que julgam ser possível escapar desse destino trágico. De certa forma, Brás Cubas considera que a melancolia é inerente à condição humana, mas, por outro lado, o fato de ser um melancólico dotado de uma lucidez suprema e absoluta o faz crer em sua superioridade em relação aos outros.

Brás Cubas morreu melancólico. Foi, também, a melancolia que lhe causou a morte. No primeiro capítulo do livro, intitulado "Óbito do autor", ele admite, galhofeiramente: "Morri de uma pneumonia; mas se lhe disser que foi menos a pneumonia, do que uma ideia grandiosa e útil, a causa da minha morte, é possível que o leitor me não creia, e todavia é verdade" (ASSIS, 2012, p. 29-30). Se essa foi a causa da morte do protagonista, foi, também, a origem do defunto-autor; portanto, esse sentimento cadencia o ritmo de Memórias póstumas de Brás Cubas e, por isso, "não é difícil antever o que poderá sair desse conúbio" (ASSIS, 2012, p. 25).

Podemos ver a melancolia do narrador-protagonista como algo inerente ao humano do final do século XIX. A já lembrada regência astral do segundo maior planeta do sistema solar suscita a dialética, algo próximo ao paradoxo melancólico, a bile que nutre com apatia e desleixo e ao mesmo tempo aguça a criticidade e a percepção. Kátia Muricy, em seu livro A razão cética: Machado de Assis e as questões de seu tempo, nos lembra que o autor demonstra bastante ceticismo diante do pensamento liberal, assim como da racionalidade burguesa. A descrença ao confrontar-se aos novos tempos "é o filtro crítico com que acolhe a entrada dos valores da modernidade europeia no Brasil" (MURICY, 1988, p. 14). Brás Cubas é materialista, mas ao mesmo tempo é capaz de reflexões metafísicas densas. Ironicamente, desdenha da 
Machado de Assis em Linha — Universidade de São Paulo

http://machadodeassis.fflch.usp.br

religiosidade, ao mesmo tempo em que narra sua história em uma condição post mortem, ação em um plano bem elevado, longe do mundano. Assim, estabelece-se uma crítica contundente aos moldes sociais daquele século, quando o narrador esboça uma mudança cosmogônica e cultural anunciando a proximidade do século XX. Distanciamo-nos da passionalidade do mal do século dos românticos, dos versos melífluos de Byron, tão caros aos dândis da época. O protagonista é do seu tempo, a melancolia é desse tempo. A profundidade de Brás Cubas encontra-se nessa rachadura, no homem cindido entre o opaco e o brilho, entre a paixão e o amor carnal. Um homem que só pode refletir sobre a vida depois de morto. Brás Cubas narra o mundo como um fenômeno monótono, sua inércia revela sua mordacidade, ao mesmo tempo que revela sua natureza frágil e débil. O protagonista escancara uma sociedade regida pela desfaçatez, emaranhada na rede sem fim das mazelas humanas. Brás Cubas é um homem do seu tempo, sua natureza melancólica configura o estado de espírito de seu tempo, recheado de ceticismo diante da realidade humana, mas sem deixar o toque sutil e irônico, a mordacidade que a condição melancólica consegue tratar muito bem. A questão é destacada quando o protagonista resolve que inventará um emplasto para arrefecer a melancolia da humanidade, algo que lhe trará o "amor da glória". Um dilema o assola, tal e qual um trapézio, acreditar no ponto de vista religioso de um de seus tios que prega que o "amor da glória" é perdição, ou acreditar no seu tio militar que considerava o "amor da glória" como a coisa mais humana no homem.

\section{Referências}

ANDRADE, Carlos Drummond de. Antologia poética. 65. ed. Rio de Janeiro: Record, 2010.

ARISTÓTELES. O homem de gênio e a melancolia: o problema XXX, I. Trad. Jackie Pigeaud e Alexei Bueno. Rio de Janeiro: Lacerda Editores, 1998.

ASSIS, Machado de. Memórias póstumas de Brás Cubas. Estabelecimento do texto, vocabulário, notas, estudos e comentários de Letícia Malard. 2. ed. Belo Horizonte: Autêntica, 2012.

BENJAMIN, Walter. Origem do drama trágico alemão. Ed. e trad. João Barrento. Belo Horizonte: Autêntica, 2011.

CHEVALIER, Jean; GHEERBRANT, Alain; BARBAULT, André et al. Dicionário de símbolos: mitos, sonhos, costumes, gestos, formas, figuras, cores, números. 
Machado de Assis em Linha — Universidade de São Paulo http://machadodeassis.fflch.usp.br

Coord. Carlos Sussekind. Trad. Vera da Costa e Silva, Raul de Sá Barbosa, Angela Melim e Lúcia Melim. 23. ed. Rio de Janeiro: José Olympio, 2009.

COUTINHO, Afrânio. Machado de Assis na literatura brasileira. Rio de Janeiro: Academia Brasileira de Letras, 1990.

FREUD, Sigmund. Luto e melancolia. Trad. Marilene Carone. São Paulo: Cosac Naify, 2011.

KEHL, Maria Rita. Melancolia e criação. In: FREUD, Sigmund. Luto e melancolia. Trad. Marilene Carone. São Paulo: Cosac Naify, 2011. p. 9-21.

KRISTEVA, Julia. Sol negro: depressão e melancolia. Trad. Carlota Gomes. Rio de Janeiro: Rocco, 1987.

MERQUIOR, José Guilherme. De Anchieta a Euclides: breve história da literatura brasileira. 2. ed. Rio de Janeiro: José Olympio, 1979.

MEYER, Augusto. Machado de Assis, 1935-1958. 4. ed. Rio de Janeiro: José Olympio; Academia Brasileira de Letras, 2008.

MURICY, Kátia. A razão cética: Machado de Assis e as questões de seu tempo. São Paulo: Companhia das Letras, 1988.

PESSOA, Patrick E. C. A segunda vida de Brás Cubas: a filosofia da arte de Machado de Assis. Rio de Janeiro: Rocco, 2008.

ROUANET, Sérgio Paulo. Riso e melancolia: a forma shandiana em Sterne, Diderot, Xavier de Maistre, Almeida Garrett e Machado de Assis. São Paulo: Companhia das Letras, 2007.

SARAIVA, Juracy Assmann. O circuito das memórias em Machado de Assis. São Paulo: Edusp, 1993.

SCHWARZ, Roberto. Um mestre na periferia do capitalismo: Machado de Assis. São Paulo: Duas Cidades; Ed. 34, 2000.

SCLIAR, Moacyr. Saturno nos trópicos: a melancolia europeia chega ao Brasil. São Paulo: Companhia das Letras, 2003.

SENNA, Marta de. Alusão e zombaria: considerações sobre citações e referências na ficção de Machado de Assis. Rio de Janeiro: Fundação Casa de Rui Barbosa, 2003.

. O olhar oblíquo do Bruxo: ensaios machadianos. 2. ed. Rio de Janeiro: Língua Geral, 2008.

Citações e alusões na ficção de Machado de Assis. Disponível em: <www.machadodeassis.net>. Acesso em: 25 jan. 2013.

SHAKESPEARE, William. Hamlet. Trad. Millôr Fernandes. Porto Alegre: L\&PM, 2009.

ZILBERMAN, Regina. Memórias póstumas de Brás Cubas: à procura da história. In: FANTINI, Marli (Org.). Crônicas da antiga corte: literatura e memória em Machado de Assis. Belo Horizonte: Ed. UFMG, 2008. p. 61-76.

- Brás Cubas autor Machado de Assis leitor. Ponta Grossa, PR: Ed. Universidade Estadual de Ponta Grossa, 2012. 
Machado de Assis em Linha — Universidade de São Paulo

http://machadodeassis.fflch.usp.br

LUCIANA BRANDÃO LEAL é Doutora em Letras (Literaturas de Língua Portuguesa) pela PUC Minas. Professora de Língua Portuguesa e suas literaturas na Universidade Federal de Viçosa, campus Florestal. E-mail: luciana_brandao@hotmail.com

ALEXANDRE VELOSO ABREU é Doutor em Letras (Literaturas de Língua Portuguesa) pela PUC Minas. Professor da Pontifícia Universidade Católica de Minas Gerais, atua no programa de pós-graduação em Literaturas de Língua Portuguesa, orientando dissertações e teses. E-mail: velosodeabreu@msn.com

Recebido: 23.07.2018

Aprovado: 15.09.2018 